\title{
MUCUNA PRURIENS: WEED, INVASIVE, OR MULTI-USE CROP
FOR THE BAHAMAS?
}

By John Hammerton

https://doi.org/10.15362/ijbs.v12i0.49

\section{Introduction}

The genus Mucuna Adanson comprises some 100 or so wild and domesticated species, native or naturalized in the tropics and sub-tropics of both hemispheres. They are lianas or vines, and include a number of species found mainly in tropical rainforests. Many Mucuna species were previously assigned to the genus Stizolobium P. Browne, and this name was proposed for annual species while retaining the name Mucuna for perennial species. Subsequent taxonomists have not maintained this separation (Mabberley, 1998). The Mucuna genus is a member of the Family Leguminosae and sub-family Papilionoideae. The taxonomy is confused with numerous synonyms: many Mucuna species have synonyms assigning them to the Dolichos L. or the Stizolobium genera. M. pruriens alone has 12 synonyms (retrieved from http:// www.mobot.org). No studies have been carried out using modern molecular techniques on the genus to eliminate this confusion (Lorenzetti et al., 1998). There is also considerable confusion with vernacular names. Only one Mucuna species occurs in The Bahamas, namely Mucuna pruriens (L.) DC., known locally as cow itch or monkey tamarind, and characterized by the irritant hairs on the pods (Correll \& Correll, 1982). Many other species in this genus also have pods with irritant hairs.

\section{Description}

Mucuna pruriens (L.) DC. is an herbaceous vine, generally tap-rooted and reproducing by seed: leaves have three leaflets up to $15 \mathrm{~cm}$ long, densely hairy beneath and rather silvery, the lateral leaflets asymmetrical. Flowers occur in showy many-flowered pendent racemes up to $30 \mathrm{~cm}$ long, dark purple and creamy-coloured. Pods are up to $12 \mathrm{~cm}$ long, oblong, thick and curved, covered with stiff brownish or orange spicules or hairs that irritate if the pods are handled. Each pod bears approximately 5,000 of these easily detached spicules, which measure ca. $2 \mathrm{~m}^{-3}$ by $20 \mathrm{~m}^{-6}$ (http://www.cdc.gov): they can blow considerable distances in the wind to cause irritation. Stored dried pods, as in herbarium specimens, retain their irritant potency. Flowering occurs from 
February to June in The Bahamas. The showy inflorescence is usually screened from view by the canopy of leaves. The species may occasionally reproduce by cuttings and behave as a short-lived perennial. Correll and Correll (1982) report it as occurring only in New Providence and Eleuthera: for purpose of reporting species distributions, these authors link these two islands. $M$. pruriens is certainly present in New Providence but not necessarily in Eleuthera. It is generally found, in New Providence, growing over fences, shrubs and small trees on vacant lots and in waste areas. It is sometimes confused with kudzu (Pueraria montana (Lour.) Merr. var. lobata (Willd.) Maesen and Almeida). The latter species has not been reported from The Bahamas but does occur in Florida (Langeland \& Burks, 1998). The present author has, over several years, received occasional calls from concerned citizens asking if the rank-growing legume in a named location is kudzu. In all cases the plants in question have proved to be $M$. pruriens.

It is native to tropical Asia but is now established throughout the American tropics, the Caribbean, and the Old World Tropics. M. pruriens and closely related species, known as "velvet beans", for obvious reasons, are cultivated worldwide. M. pruriens has been investigated for its phytochemistry (Lorenzetti, 1998).

\section{Regional Distribution}

Table 1 lists the Mucuna species present in the Caribbean, including The Bahamas, and gives their distribution, though this should not be taken as definitive. Note the synonyms. Adams (1972) records five species in Jamaica, but he states that $M$. urens is "[V]ery rare and not recently collected"; $M$. fawcettii is an endemic but is also very rare; and $\mathrm{M}$. deeringiana is described as "sparingly cultivated". Fournet (1978) records five species in Guadeloupe and Martinique, including the cultivated $M$. aterrima and $M$. deeringiana. Fournet \& Hammerton (1991) report $M$. pruriens as present in all the islands of the Lesser Antilles. Gooding et al. (1965) list M. urens as also present in Barbados, but report no recent collection, and they state that $M$. aterrima is "commonly planted as a green dressing". Burks (pers. comm., 2001) reports that M. sloanei occurs occasionally in hammocks in Miami-Dade and Broward Counties in Florida, and that M. pruriens is naturalized in a number of South-eastern Florida Counties, including the Keys.

\section{Status}

M. pruriens cannot be considered a serious weed on a global scale. Holm et al. $(1977,1997)$ do not list it as among the 180 worst weeds in the world. Holm et al. (1979), in their atlas of world weeds, do however list M. pruriens as "serious" in two countries (Mexico and Mozambique), as a "principal weed" also in two countries (Jamaica and Madagascar), and as a "common" weed in four countries (Guatemala, Kenya, Micronesia and Tanzania). It is reported as "present" as a weed in 16 countries, including the Dominican Republic and Puerto Rico. Cardenas et al. (1972) consider $M$. pruriens "common in cultivated fields, perennial crops, pastures, roadsides, and fencerows" in Latin America and the Caribbean. Ivens et al. (1978) regard M. pruriens as occurring “...throughout the tropics and common in West Africa in abandoned cultivation and forest clearings". Fournet \& Hammerton (1991) describe it as almost exclusively a weed of cane fields in the Lesser Antilles, and Fournet (1978) describes it as also growing over bushes and hedges in Guadeloupe and Martinique. Adams 
Table 1. The Mucuna species of the Caribbean Region, including Florida and The Bahamas, with notes on vernacular names, and characteristics and distribution.

\begin{tabular}{lll}
\hline Botanical name $^{1}$ & Vernacular name(s) $^{2}$ & Characteristics and distribution $^{3}$ \\
\hline $\begin{array}{ll}\text { M. aterrima } \\
\text { (Piper \& Tracy) }\end{array}$ & $\begin{array}{l}\text { Bengal bean, Mauritius } \\
\text { bean, velvet bean. }\end{array}$ & $\begin{array}{l}\text { Flowers purple; pods with white adpressed } \\
\text { hairs but black at maturity, without irritating Holland } \\
\text { hairs; seeds black with a white hilum. Barbados, } \\
\end{array}$ \\
& $\begin{array}{l}\text { Guadeloupe, Martinique, Trinidad and Tobago. } \\
\text { Synonym for M. pruriens var. utilis. }\end{array}$ \\
\hline
\end{tabular}

\begin{abstract}
M. deeringiana Florida velvet bean
(Bort) Merr.
\end{abstract}

Flowers purple; pods ca. $7 \mathrm{~cm}$ long, grayish and sparsely hairy but without irritating hairs; seeds marbled and round. Florida, Guadeloupe, Jamaica, Martinique, Trinidad and Tobago. Synonym for M. pruriens var. utilis.

M. fawcettii Urb. None found.

Flowers yellow: pods 1-2 seeded with stiff hairs. Jamaican endemic.

M. nivea (Roxb.) Lyon bean.

DC.

Flowers white; pods ca. $14 \mathrm{~cm}$ long and S-shaped, with white adpressed hairs when green. Trinidad and Tobago. Synonym for M. pruriens

M. pachylobia ${ }^{4} \quad$ Bengal bean, velvet bean Rock

Flowers purple; pods $12-16 \mathrm{~cm}$ long and fleshy when green, with sparse soft hairs. Trinidad and Tobago.

\begin{tabular}{ll} 
M. pruriens & 5 (L.) \\
DC. & Buffalo bean, cowage, \\
& cowhage, cow itch, cowitch, \\
& hell fire weed, itchweed, \\
& itchy weed, monkey \\
& tamarind, nescafe, \\
& velvet bean. \\
\hline
\end{tabular}

Flowers dark purple and creamy; pods ca. 12 $\mathrm{cm}$ long with reddish-brown irritating hairs. Throughout the Caribbean, including Cuba, Dominican Republic, Haiti and the Cayman Islands, and Florida.

\begin{tabular}{ll}
$\begin{array}{l}\text { M. pruriens var. } \\
\text { utilis (Wall. ex } \\
\text { Wight) } \\
\text { Baker ex Burck }\end{array}$ & $\begin{array}{l}\text { Bengal bean, Mauritius } \\
\text { bean, caf Brazilii, } \\
\text { Portuguese coffee, velvet } \\
\text { bean. }\end{array}$ \\
\hline $\begin{array}{l}\text { M. rostrata } \\
\text { Benth. }\end{array}$ & None found. \\
\hline $\begin{array}{l}\text { M. sloanei } \\
\begin{array}{l}\text { Fawc. \& } \\
\text { Rendle }\end{array}\end{array}$ & $\begin{array}{l}\text { Horse-eye bean, donkey- } \\
\text { eye }\end{array}$
\end{tabular}

Flowers purple and creamy; pods covered with velvety hairs and lacking irritant hairs; seeds variable in colouring. A cover and green manure crop.

Flowers ca. $7 \mathrm{~cm}$ long, orange-scarlet independent racemes. Trinidad and Tobago.

Flowers lemon-yellow; pod ca. 10-15 cm long by $4 \mathrm{~cm}$ broad,very hairy with irritating hairs. Florida, Guadeloupe, Jamaica, Trinidad and Tobago. A synonym of M. urens.

$\begin{array}{ll}\text { M. urens (L.) } & \text { donkey-eye bean, } \\ \text { Medic. } & \text { horse-eye }\end{array}$

Flowers purple and yellow, pod with irritating hairs, bean, ox-eye bean seeds roundish and ca. $3 \mathrm{~cm}$ across Barbados, Guadeloupe, Martinique and Jamaica
M. utilis (Wall. ex See M. pruriens var. utilis. See M. pruriens var. utilis. Wight) Baker ex Burck

1 Authors correspond to those in VAST (Vascular Tropicos, the nomenclatural database of the Missouri Botanic Gardens at http://www.mobot.org), but this database gives no vernacular names. Other useful databases for nomenclature are Species $2000 \mathrm{~s}$ Catalogue of Life (at http://www. sp2000.org) and the International Legume Database and Information Service (ILDIS) (at http://www. ildis.org, or at http://www.biodiversity.soton.ac.uk).

2 Sources are various Floras and also ILDIS (see above). The specific name nivea means snowywhite ; pachy- means stout or thick and-lobium means podded, hence thick-podded; pruriens means stinging or irritating : utilis means useful ; rostrata means beaked or with a long straignt point ; urens means stinging or burning ; and ater- means matt black (Gledhill, 1989).

3 Sources are various Floras and also ILDIS (see above).

$4 \mathrm{M}$.pachylobia is not listed by Species2000: Williams and Williams (1969) record it as M. pachylobium. 
(1972) records it as "frequent in cultivations, thickets and woodland margins" in Jamaica. In Barbados it is reported to be mainly a weed of cane fields, primarily in the higher parts of the island (Gooding et al., 1965). Neither the Global Invasive Species Database (GISP) of the World Conservation Union (IUCN) (retrieved at http://www.issg.org/database/welcome/html), nor the Florida Exotic Pest Plant Council (FLEPPC, 2001), or other Pest Plant Councils in the Southern USA (see http:/ / www.exoticpestplantcouncil.org) lists M. pruriens as an invasive species. Hammerton (2002) suggests that this species bears watching closely for invasiveness.

\section{Uses}

The Mucuna species known as "velvet beans" (M. aterrima, M. deeringiana, M. nivea, M.pruriens var. utilis, and M. utilis) lack stinging hairs and, together with $M$. pruriens (with stinging hairs, but also known as "velvet bean"), have a history of multiple uses in agriculture and, because they contain biologically active compounds, also in medicine. $M$. pruriens has a long history of use as a medicinal plant, which is well documented.

The hairs (or spicules) on the ripe pods of $M$. pruriens are notorious for their capacity to cause itching. Just how pervasive these hairs can be is illustrated by a report from the United States Centers for Disease Control and Prevention (CDC). In October 1985, two emergency medical technicians (EMTs) responded to a call reporting two persons with severe pruritus (itching of the skin without visible eruption). The two EMTs also developed pruritus soon after arrival on site, and all four persons went to an emergency room, where they received treatments. The symptoms disappeared within an hour or two. The admitting nurse, who had put an arm around one patient, also developed pruritus on her inner forearms. This was resolved by washing with soap and water. A policeman who went to the apartment, and a worker who collected trash outside the apartment the following day, also developed pruritus and received emergency room treatment. The cause was identified as $M$. pruriens pods. Studies have shown that introduction of just one spicule through the skin leads to a burning itch, but spicules can be removed by washing or by applying adhesive tape. A protein, mucunain, has been identified as the active pruritic agent (retrieved from http://www.cdc.gov).

\section{Anthelmintic}

The spicules have in the past been (and may still be) sold commercially as "itching powder". Up until the 1950s they were also used as an oral vermifuge (anthelmintic) (retrieved from http://www.cdc.gov). Felter \& Lloyd (1898), in "King's American Dispensatory", referring to M. pruriens, state that "[T]he medicinal part of the plant is the hair of the pods, which are generally imported into this country attached to the pod, and from which they are carefully removed, so that they do not fasten to the operator's hands." They report that a decoction or tincture of the spicules has no anthelmintic properties, suggesting that the action is physical: the worms are irritated and expelled alive. Administration was in syrup or molasses, followed a few hours later by a purgative. This treatment was reportedly used in the Caribbean and Central America.

\section{Pharmacology}

M. pruriens features in Indian Ayurvedic Medicine, an ancient system based 
on scientific principles (retrieved from http://ayurveda.com; http://niam. com; and http://www.ayurvedahc.com). Uses include as an "anodyne, antidotal, aphrodisiac, diuretic, nervine, resolvent, rubefacient, and vermifuge", and it is used for "anasarca, asthma, cancer, cholera, cough, diarrhea, dog bite, dropsy, dysuria, insanity, mumps, pleuritis, ringworm, snakebite, sores, syphilis, tumors, and worms" (retrieved from http:/ / www.rain-tree.com and http:// www.holisticonline.com). This is an extraordinarily wide range of complaints, but another website (http://www.herbweb.com) adds "antidote (crocodile), antidote (scorpion)" and "cough (and) fractures"! The ingredients of Ayurvedic medicines, including $M$. pruriens seed powder, are advertised at a number of web sites (for example, http://herbnet.com; http://banyanbotanicals.com; and http://ayurveda-herbs.com). Oudhia (2001) reports that M. pruriens is a constituent of more than 200 indigenous drug formulations in India and that there is a heavy demand for M. pruriens in Indian drug markets. After the discovery that Mucuna seeds contain L-dopa, the demand motivated many Indian farmers to start commercial cultivation.

Table 2 gives examples of the complaints, preparations and administration of M. pruriens in Ayurveda. This Table should not be taken to imply either recommendation, or endorsement as to efficacy, by the current author. M. pruriens is not apparently recognized as a medicinal plant in the Caribbean at the present time: neither Seaforth et al. (1983), in their book on the medicinal plants of Trinidad and Tobago, nor Honychurch (1986), in her book of useful plants of the Caribbean, mention it. Similarly, neither Higgs (1974) nor Jordan (1986) list it as a medicinal plant in The Bahamas, no doubt in part due to its limited distribution.

M. pruriens plants contain a large number of chemical compounds: one webTable 2. Some Indian medical uses of Mucuna pruriens. These are cited solely as examples and no recommendation of any of the treatments is to be implied by this listing.

\begin{tabular}{|c|c|c|}
\hline Complaint & Preparation & Administration \\
\hline $\begin{array}{l}\text { Abdominal } \\
\text { discomfort }\end{array}$ & $\begin{array}{l}\text { Grind the root to make } \\
\text { paste. }\end{array}$ & $\begin{array}{l}\text { Take paste orally once a day for two a } \\
\text { days. }\end{array}$ \\
\hline Cholera & $\begin{array}{l}\text { Boil roots with four litres } \\
\text { of water and filter. }\end{array}$ & $\begin{array}{l}\text { Take one glass orally with honey eight } \\
\text { times a day until cured. }\end{array}$ \\
\hline Infertility in men & $\begin{array}{l}\text { Put } 10 \text { grams of roots in a } \\
\text { glass of milk: the milk will } \\
\text { go black. }\end{array}$ & $\begin{array}{l}\text { Take a glass of this milk orally once a } \\
\text { day in the evening for seven days }\end{array}$ \\
\hline Scorpion sting & $\begin{array}{l}\text { Grind seeds with water to } \\
\text { make a paste. }\end{array}$ & $\begin{array}{l}\text { Apply the paste to the affected area } \\
\text { twice a day for four days. }\end{array}$ \\
\hline Snake-bite & $\begin{array}{l}\text { Extract juice from the } \\
\text { roots. } \\
\text { Grind } 100 \text { grams of roots } \\
\text { to make a paste and mix } \\
\text { with } 50 \text { grams of molasses. }\end{array}$ & $\begin{array}{l}\text { Take orally one teaspoonful three or } \\
\text { four times continuously (sic). } \\
\text { Take the paste orally with water just } \\
\text { after the snake-bite has occurred. }\end{array}$ \\
\hline Toothache & $\begin{array}{l}\text { Sun dry the roots and } \\
\text { grind to a powder. }\end{array}$ & Apply the powder to the aching teeth. \\
\hline Worm infection & $\begin{array}{l}\text { Grind the root with the root } \\
\text { of Cassia occidentalis } L \text {. } \\
\text { (coffee senna) to make a paste. }\end{array}$ & $\begin{array}{l}\text { Take the paste orally with a glass } \\
\text { of water once a day for three days. }\end{array}$ \\
\hline
\end{tabular}

Source: http://www.mssrf.org.sg. 
site (http://www.rain-tree.com) lists fifty-two. Several have pharmacological properties, including L-dopa (3-(3,4-dihydroxyphenyl) alanine), nicotine and serotonin, and allegedly a number of tryptamines (which have hallucinogenic properties: see below). L-dopa is used in the treatment of Parkinson's disease, a neurological disease affecting the part of the brain that produces dopamine, a substance that allows impulses to be sent from one nerve cell to another. In Parkinson's disease insufficient dopamine is produced, and the symptoms include trembling, stooped posture, poor balance and slowness of body movements (Manyam \& Cryer, n.d.). M. pruriens seeds have been used for the treatment of Parkinson's disease for over 4,500 years in Ayurveda. Animal trials have suggested that $M$. pruriens L-dopa is two to three times more effective than equivalent amounts of synthetic L-dopa, suggesting either that $M$. pruriens contains compounds that enhance the efficacy of L-dopa, or that constituents of $M$. pruriens independently reduce the symptoms (Manyam \& Cryer, n.d.). They emphasize the need for more research. L-dopa is a known libido-booster, and has also been suggested as an alternative to Viagra ${ }^{\circledR}$ (retrieved from www.herbal-viagra-alternatives.online.com).

\section{Feed and Food}

Cattle can be fed a meal of velvet beans ground in the pod, but there are reports that pigs, poultry and horses do not do well on this feed (Lorenzetti et al., 1998). The pods and seeds contain several toxic principles, and for human consumption boiling with repeated changes of the water, and removal of the testa, are necessary to reduce toxicity. These authors cite an example of the potential danger: more than 200 cases of acute toxic psychosis occurred in 1989 in Mozambique attributable to the consumption of $M$. pruriens seeds. The usual practice of discarding the cooking water was not adopted because of a drought. Mucuna beans are not ideally suited for human consumption.

Lorenzetti et al. (1998) report on chemical analyses of the seeds of 36 accessions of "velvet bean", representing many common cultivars worldwide. They detected no tryptamines in any of the accessions, and comment that, although there are reports of tryptamines in the Mucuna genus (see above), no "primary journal article reports tryptamines specifically in the seed of $M$. pruriens". They also analyzed for L-dopa, and found that contents ranged from a low of $2.2 \%$ of dry weight to a high of $6.2 \%$. There was evidence of genetic variation, and it was also observed that L-dopa content varied between locations. A linear regression of L-dopa content on latitude accounted for $78 \%$ of the variation: the regression coefficient was negative, indicating that L-dopa levels decreased with latitude (or distance from the equator). Although processing (for human consumption) is one option, there is still a risk of intoxication with the consumption of high L-dopa seeds: low L-dopa genotypes are clearly desirable. However, the reductions in the content of L-dopa and other phytochemicals, might reduce the plant's ability to protect itself against predators as, at present, Mucuna species are relatively free of the insect problems that beset other legumes. The numerous species and cultivars presently in use need to be catalogued using agreed descriptors.

\section{Agriculture}

Velvet beans were extensively cultivated in the southern United States during the early 1900s as cover and green manure crops, and as forage and feed. The acreage declined in the mid-1940s, partly as the result of a drop in the real price of commercial fertilizers (Buckles et al., 1998a). The latter authors pro- 
vide an excellent history of velvet beans and another useful source of references is http:// www.newcrops.uq.edu.au. Velvet beans are reasonably tolerant of drought and low soil fertility, but are sensitive to cold and thrive best in warm and moist climates. They have the potential to fix atmospheric nitrogen by symbiosis with Rhizobium and are non-specific in their Rhizobium requirement. It is claimed that velvet beans can fix up to $150 \mathrm{~kg} \mathrm{ha}^{-1}$ year $^{-1}$ of nitrogen, which can then benefit a following (non-legume) crop by the release of this fixed nitrogen into the soil (retrieved from http://www.new-agri.co.uk). The rainfall range is considered to be 650 to 2,500 mm year ${ }^{-1}$ (retrieved from http://www.fao.org). Velvet beans are capable of smothering weeds and shrubs, and shed significant quantities of leaves before reaching maturity: these leaves serve as mulch and decay on the soil surface. Quantities of aboveground biomass vary from five to more than twelve $\mathrm{tha}^{-1}$ dry-matter, and root dry-matter may exceed $1 \mathrm{t} \mathrm{ha}^{-1}$. Pod production varies widely but may exceed $2 \mathrm{t} \mathrm{ha}^{-1}$ (Buckles et al., 1998a). Velvet beans can produces up to $35 \mathrm{t} \mathrm{ha}^{-1}$ of organic matter, which can improve soil properties (retrieved from http:// www.new-agri.co.uk). Purseglove (1968) in his book on tropical dicotyledonous crops, comments that Stizolobium deeringiana Bort. (syn. M. deeringiana) is better suited to colder climates than M. aterrima.

Velvet beans can be ensiled but do not make good hay. For grazing, animals are usually turned in after the pods are mature: yields of up to $19 \mathrm{t} \mathrm{ha}^{-1}$ of green forage and nearly four $\mathrm{tha}^{-1}$ of seed are reported. Velvet beans are also effective in smothering weeds (retrieved from http://www.fao.org) partly, it is suspected, because of allelopathy, as well as competition for light. The use of Mucuna species to suppress weeds in a crop is also known as "live mulching". Imperata cylindrica (L.) Pal (cogon grass), an aggressive weed in many parts of the tropics (Holms et al., 1979), is effectively controlled by a live mulch or cover crop: for example, $M$. pruriens var. utilis grown prior to cassava cultivation effectively suppressed I. cylindrica and other weeds. Cassava cuttings could be planted directly into the mulch with little or no land clearing or preparation (retrieved from http://www.iita.org/info).

Velvet beans were probably introduced into Mesoamerica in the 1920s by the United Fruit Company as a forage crop for the company's mules on their banana plantations, principally along the Atlantic coast of the isthmus. They became known as "banana field beans" (Buckles et al., 1998a). Local farmers readily adopted them, recognizing their ability to maintain soil fertility without the use of chemicals. In northern Honduras, a field of velvet beans came to be known as an abonera, or "fertilized field", and the seed as frijol de abono, or "fertilizer bean". In Mesoamerica, velvet beans are generally intercropped with maize. After the maize crop is harvested, the field is abandoned to the spontaneous growth of velvet beans. The purpose of this "velvet bean fallow" is to maintain and increase soil fertility for the benefit of the subsequent maize crop: there is no direct economic gain from the velvet bean fallow itself. The abonera system resembles a natural ecosystem with a largely undisturbed mulch layer. This not only benefits soil fertility but also reduces soil erosion, so that the abonera system is a viable long-term option for continuous hillside cultivation (Buckles et al., 1998b). The nutrients within the ecosystem are released through decomposition of the velvet bean mulch, which is created by slashing and maintained by not burning it.

Numerous farm-families in Mesoamerica are presently benefiting from the adoption of the abonera system using velvet beans. Maize yields have at least 
doubled or tripled, and there are reports of increases from ca. $500 \mathrm{~kg} \mathrm{ha}^{-1}$ to $2000 \mathrm{~kg} \mathrm{ha}^{-1}$ or more. Farmers are reported as saying that their lands are now producing adequate food on a sustainable basis such that they no longer need to cut down virgin forest. Other crops in other parts of the world show similar yield increases from the use of velvet beans as cover crops or live mulches (retrieved from http://www.new-agri.co.uk). Buckles et al. (1998b) report that once the velvet bean rotation is established, greater yield stability is achieved in the face of adverse climatic conditions: there is less risk of low yields compared with other cropping systems.

One problem is that the quick reestablishment of the velvet bean competes with the growing maize crop in certain years, making pruning and cutting back (of the velvet beans) necessary. Buckles et al. (1998b) record another problem, which they call "the Rottboellia puzzle". R. cochinchinensis (Lour.) W. Clayton (syn. R. exaltata L. f.) (known in The Bahamas as "itchgrass"), began invading fields in Honduras after typhoon Fifi (in 1974): seed may have been introduced to northern Honduras with food aid. It is an extremely aggressive grass weed (Holms et al., 1979), and spread rapidly to communities close to the main coast road, apparently finding an ideal environment in the abonera system. The Mucuna crop controls most weed species, especially broadleaf species, but nutrients, light, and water are available after the slashing of the velvet beans and before full establishment of the maize crop. Reliance on natural reseeding of Mucuna allowed gaps to form in the Mucuna stand, which were quickly invaded by Rottboellia. Clearly, the use of Mucuna entails some management skills.

\section{Miscellaneous Uses}

The large seeds of Mucuna species are variously coloured and often mottled, and are used as beads for necklaces in many countries, often in combination with other legume seeds (retrieved from http://www.waynesword. palomar. edu). Seeds of many Mucuna species are distributed by water, and are known in some countries as "sea beans", because they wash up on beaches, where they are sometimes collected as lucky charms. In Mexico and Central America the beans are strung as lucky charms ("Ojo de venado" or "Eye of the deer") with a Catholic saint printed on one side of the seed. These are carried as "pocket-pieces" or hung on rear-view-mirrors (retrieved from http://www. luckymojo.com).

\section{Discussion}

The present distribution of Mucuna pruriens in The Bahamas is not reliably known: it may have been introduced beyond New Providence where it appears to be spreading. Many people are familiar with this species, having become uncomfortably aware of its propensity to cause itching, even at a distance. It would seem to be a potential invasive species, as it overgrows shrubs and small trees. There is no record of any Mucuna spp. being grown and evaluated as forages, green manure crops, or live mulches in The Bahamas. The Bahamas Agricultural Research Training and Development (BARTAD) Project, which was funded by USAID with counterpart funding by the Government of The Bahamas, evaluated a number of forage legumes when grown alone and in mixtures with various grasses, at the project site in North Andros over the period 1973 to 1978, (Kyle \& McAlexander, 1978). These trials included some legume species already present in The Bahamas (Stylosanthes spp. for exam- 
ple), though seed of improved varieties was imported for the trials. A number of introduced species, such as Glycine wightii,Desmodium spp. and Centrosema pubescens, were also evaluated (Guyton \& Baylor, n.d.: Wilson et al., n.d.). Mucuna species (velvet beans) were not included in these trials, possibly because by that time velvet beans had declined in importance in the USA (Buckles et al., 1998a). Cathopoulis (pers. comm., 2002), who was actively involved in this work, confirmed that velvet beans were not included in any trials and that, to the best of his knowledge, no private farmer had ever introduced and evaluated velvet beans.

\section{Suggested Potential Uses in The Bahamas}

It is suggested that velvet beans merit evaluation in The Bahamas as the basis of sustainable agriculture systems, for both small- and large-scale farmers. Given the immaturity and relatively low fertility of Bahamian soils (Sealey, 1994) velvet beans would add organic matter and nitrogen to the soil, as well as smaller quantities of other major nutrients and, over time, increase soil fertility. Velvet beans might also be a useful forage crop. Specific potential uses include:

Live Mulch in Orchard Crops. Establishment of velvet beans in existing orchards for weed control, and to provide nitrogen, would require minimal preparatory cultivation. Pruning would certainly be necessary to prevent intrusion of the live mulch into the tree canopy. Sheep might be an alternative to pruning. It would be important to maintain a complete ground cover at all times. Management regimes should seek, inter alia, to ensure annual reseeding, and the fertilizer requirements of the live-mulched crop would need to be reassessed.

Forage Crop for Ruminants. Velvet beans could provide a useful forage crop, perhaps in combination with one or more grass species, and could provide the legume component of a "forage bank", where an area is fenced (to prevent grazing) for a time so as to provide accumulation of forage for the dry season. In this system, animals are either fed by cut-and-carry or by controlled and limited access. Siratro (Macroptilium atropurpureum (DC.) Urb.), which was tested at BARTAD, might also be successfully used in forage banks and pastures (Cathopoulis, pers. comm., 2002). A literature search would be necessary to identify the best species and cultivars, and the optimum management for both pastures and livestock.

Silage for Ruminants. Silage making is not familiar to Bahamian livestock farmers and the technical and economic feasibility needs to be researched. Velvet bean/grass mixtures can be ensiled (retrieved from http://www.fao.org) but flail-type harvesters are necessary (as compared to reciprocating knife mowers). The need for such specialized machinery would make this use more appropriate for large-scale operations.

Cover (or Fallow Crop) in Slash-and-Burn Subsistence Systems. Velvet beans could form the basis of sustainable farming systems by obviating the need for a fallow ("resting" or "recovery") period. The abonera system, as currently practised in Mesoamerica, provides a useful pattern. This system would also be appropriate for the home garden where this is an important source of food for the household, as in some Family Islands. Avoidance of slash-and-burn would also benefit the conservation of wildlife. This would be a "low external input agriculture" (LEIA) system.

Organic Farming Systems. Use of velvet bean for building soil fertility, by providing nitrogen for increasing soil organic matter and water-holding capacity, 
would provide a basis for true organic farming, with no use of chemical fertilizers or pesticides. If necessary, velvet beans could be grown specifically for composting, with other organic wastes, to provide mulching material. There are niche markets for organic produce both locally (though the demand has not been tested) and overseas.

\section{Research Needs}

The following is not a comprehensive list and is intended only to pinpoint information needs.

Species and Varieties. A literature search, and small-scale field trials of potentially useful species and cultivars, to generate data on forage and dry matter yields and other parameters is needed. Clearly, only species and cultivars with non-irritant hairs would be selected for evaluation.

Management. Trials to determine optimal times of grazing and/or cutting (for silage or forage), fertilizer requirements, pruning management (in live mulch systems), and resting periods (to allow for natural seeding).

Forage and Feed. Appropriate mixtures with grasses for grazing (and possibly for silage) and any constraints to daily intake to avoid intoxication.

Labour Use. Labour needs for pruning or chopping in live mulch systems to prevent the velvet beans overwhelming the crop.

Markets. Market research to determine the potential demand for organically grown produce.

Protocol for Introduction. No introductions of Mucuna species should be undertaken without a careful review of the potential benefits and costs (environmental and economic) and approval by a competent government authority. Hammerton (2002) has suggested a number of components of a protocol for plant introductions. These include a clear demonstration of benefits; primary introduction to be into approved areas away from natural habitats, forest reserves, and national parks: confirmation of the taxonomy of the proposed introduction(s) before introduction; and initial introductions to be into small, closely monitored field plots under strict quarantine.

\section{Notes}

I thank Mrs. Valerie Outten, Acting Director of Agriculture, for providing access to the Department's BARTAD Reports, and Mr. T.E. Cathopoulis (T.C.) for a useful and stimulating discussion on forages in The Bahamas. Mrs. Kathy Burks of the Florida Department of Environmental Protection, Tallahassee, Florida, also provided useful information by e-mail. All opinions expressed are those of the author, however.

\section{References}

Adams, C.D. (1972) Flowering plants of Jamaica. University of the West Indies, Mona, Jamaica.

Buckles, D., Etèka, A., Osiname, O., Galiba, M. \& Galiano, N. (Eds). (1998a) Cover crops in West Africa. Contributing to sustainable agriculture International Development Research Centre/International Institute of Tropical Agriculture, Ottawa Canada. Retrieved online from http://www.idrc. ca

Buckles, D., Triomphe, B. \& Sain, G. (1998b). Cover crops in hillside agriculture. Farmer innovation with Mucuna. International Development Research Centre/International Institute of Tropical Agriculture, Ottawa 
Canada. Retrieved online from http://www.idrc.ca.

Cardenas, J, Reyes, C.E., \& Doll, J.D. (1972) Tropical weeds. Malezas tropicales. Instituto Colombiano Agropecuario, Bogota, Colombia.

Correll, D.S. \& Correll, H.B. (1982) Flora of the Bahama Archipelago. Gantner Verlak K-G, Germany.

Felter, H.W. \& Lloyd, J.U. (1898) King's American Dispensatory. OR: EM Publications, USA. Retrieved online from http://ibiblio.org/herbmed/eclectic/kings.main.html.

FLEPPC. 2001. List of Florida's Invasive Species. Florida Exotic Pest Plant Council Retrieved online from http://www.fleppc.org/01list.htm.

Fournet, J. (1978) Flore illustree des phanerogames de Guadeloupe et de Martinique. Institute National de la Recherche Agronomique, Paris, France.

Fournet, J. \& Hammerton, J.L. (1991) Weeds of the Lesser Antilles. Mauvaises herbes des Petites Antilles. Institut National de la Recherche Agronomique, Paris, France.

Gledhill, D. (1989) The names of plants. Cambridge University Press, Cambridge, England.

Gooding, E.G.B., Loveless, A.R. \& Proctor, G.R. (1965) Flora of Barbados. Her Majesty's Stationery Office, London, UK.

Guyton, R.F. \& Baylor J.E. .(n.d.). Observations on the performance of several tropical legumes. Final Report No. 24.

Hammerton, J.L. (2002) Invasive alien plants to look out for. Bahamas Journal of Science: 9.

Higgs, L. (1974) Bush medicine in The Bahamas. The Nassau Guardian (1884) Ltd., Nassau, Bahamas.

Holm, L.G., Plucknett, D.L., Pancho, J.V. \& Herberger, J.P. (1977) The world's worst weeds. Distribution and biology. University of Hawaii Press, Honolulu, Hawaii, USA.

Holm, L., Doll, J., Holm, E., Pancho, J. \&.Herberger, J. (1997) World weeds. Natural histories and distribution. John Wiley \& Sons, New York, USA.

Holm, L., Pancho, J.V., Herberger, J.P. \& Plucknett, D.L. (1979) A geographical atlas of world weeds. John Wiley \& sons, New York, USA.

Honychurch, P.N. (1986) Caribbean wild plants and their uses. Macmillan Publishers, London, England.

Ivens, G.W., Moody, K. \& Egunjobi, J.K. (1978) West African weeds. Oxford University Press, Ibadan, Nigeria.

Jordan, P.B. (1986) Herbal medicine and home remedies. A potpourri in Bahamian culture. The Nassau Guardian Printing Press, Nassau, Bahamas.

Kyle, L.R. \& McAlexander, R.H. (1978) Final report on BARTAD by The Penn State University under contract no. AID/CM/ta-C-73-28. July 11973 to January 181978.

Langeland, K.A. \& Burks, K.C. (Eds.). (1998) Identification and biology of nonnative plants in Florida's natural areas. Institute of Food and Agricultural Sciences Publications, University of Florida, Gainesville, USA.

Lorenzetti, F., MacIsaac, S., Arnason, J.T., Awang, D.V.C. \& Buckles, D. (1998) The phytochemistry, toxicology, and food potential of velvetbean (Mucuna Adans. spp., Fabaceae). In Buckles, D., Etèka, A., Osiname, O., Galiba M. \& Galiano, N. (1998) Cover crops in West Africa. Contributing to Sustainable Agriculture International Development Research Centre/International Institute of Tropical Agriculture, Ottawa Canada. (Retrieved online from http://www.idrc.ca). 
Mabberley, D.J. (1998) The plant-book. A portable dictionary of the vascular plants. Cambridge University Press, Cambridge, England.

Manyam, B.V. \& Cryer, G.R. (n.d.) Beans (Mucuna pruriens) for Parkinson's Disease: An herbal alternative. National Parkinson Foundation. Retrieved online from http://www.parkinson.org/beans.htm.

Oudhia, P. (2001) Kapikacha or cowhage (Mucuna pruriens). Retrieved online from $h t t p: / / w w w . h o r t . p u r d u e . e d u / n e w c r o p$.

Purseglove, J.W. (1968) Tropical crops. Dicotyledons. Longmans, London, England.

Seaforth, C.E., Adams, C.D. \& Sylvester, Y. (1983) A guide to the medicinal plants of Trinidad and Tobago. Commonwealth Secretariat, London, England.

Sealey, N.E. (1994) Bahamian Landscapes. An introduction to the geography of The Bahamas. Media Publishing, Nassau, Bahamas.

Williams, R.O. \& Williams, R.O. (1969) The useful and ornamental plants of Trinidad and Tobago. Government Printery, Trinidad and Tobago.

Wilson, L.L., Katsigianis, T.S., Dorsett, A.A., Cathopoulis, T.E., Guyton, R.F., Greaves, A.G. \& Baylor, J.E. (n.d) Improved pastures for goat production. Final Report No. 33.

Dr. John L. Hammerton is an agronomist and weed scientist with a Ph.D. from the University of Wales. He has lectured at the University of Wales and the University of the West Indies in Trinidad, and worked in agricultural research and development in Jamaica, Belize, Barbados and St. Lucia. More recently, he has served as an Assistant Director of Agriculture and as Chief Scientist to the Bahamas Environment, Science and Technology (BEST)Commission. He retired in 2000. 